Article

\title{
Clan in Transition: Societal Changes of Villages in China from the Perspective of Water Pollution
}

\author{
Qidong Huang ${ }^{1, *}$, Jiajun $\mathrm{Xu}^{1}$ and Yongping Wei ${ }^{2}$ \\ 1 School of Public Administration, Hohai University, Nanjing 211100, China; xujiajun2004@126.com \\ 2 School of Earth and Environmental Sciences, the University of Queensland, 4067 Brisbane, Australia; \\ yongping.wei@uq.edu.au \\ * Correspondence: huangqidong@hotmail.com; Tel.: +86-258-576-7526
}

Received: 24 November 2017; Accepted: 5 January 2018; Published: 10 January 2018

\begin{abstract}
Societal relations in rural areas have entered into a new stage of adjustment over the past decade. However, the adjustment, which might bring about profound societal changes in countryside as well as in China as a whole, have not been paid much attention and very few studies have been conducted from the perspective of ecological resource crises. We use the case of a village as an example to show how water pollution, as one of the contributory factors, possibly affect the transition of clans and societal changes in Chinese villages. Through observation and interviews, we find that there is an apparent rise of "New Clanism" within clans, which gradually abandons the tradition of supremacy of clan interests and places family or individual interests at top priority. We also find that clan boundaries get increasingly obscure since the integrity of clans is undermined by the rise of new interest groups across clans, but the boundaries remain relatively clear due to the consistency (albeit incomplete) of clan interests. Some new clan élites and representatives of new interest groups get involved in village governance, which indicates that their goals have shifted from natural resources to social or political capital. The significance of our findings is that they provide not only a unique perspective for the interaction between society and resources, but also some new ideas for the future study of rural China at the environment-social interface.
\end{abstract}

Keywords: clan in transition; societal changes; water pollution; ecological resource crises

\section{Introduction}

Clans in the rural areas of China, with their members living in same areas and sharing similar resources, are social organizations based on ties of consanguinity and geography. The orders and rules followed by the clans are one of the most important informal systems in rural China. Clan members usually share similar social capital and natural resources and form basically unanimous interest groups. Clans are now experiencing great changes with the transition of China's society. In response, scholars have increasingly focused their attention on clan transitions [1]. However, despite the progress, knowledge of the causes and results of the transitions remains limited, especially in relation to ecological resource crises as possible factors that lead to clan transitions. The ecological resource crises refer to the imbalance of the structures and functions of the local and even the global resource system caused by the excessive production and living activities of human beings. The crises are not only limited to the shortage of natural resources, but related to the decline of environment and resources, thereby affecting the sustainable development of society.

Built on the interwoven relationship of geography and consanguinity, clans are specific forms of communities with certain historical and cultural heritages. Clans, typical social organizations in rural China, formed naturally under centralized bureaucratic state system thousands of years ago. Clan systems not only constitute the social basis for the rule of the state, but also meet the needs of the maintenance of the local social order and the demands of economic cooperation. Weber claims that the 
village areas in China are often autonomous regions and the management of villages is usually in the hands of the villagers themselves [2]. Fairbank points out that civil dispute mediation in traditional rural society in China relies more on traditional rules left over from their clan ancestors than laws introduced from the outside world [3]. Clans also have the characteristic of closeness. Fukuyama claims that clans are maintained by kinship and anyone outside of the clan is considered an outsider [4].

Clan gentries and clan conventions (or rules) are two indispensable and interrelated elements in the patriarchal system. Gentries are normally the leaders of clans or villages, and their power comes not from the central empire, but from the local villagers and clan conventions. They always coordinate the community's public affairs, come into contact with the governments as the representatives of villages or clans and play a strategic role in the negotiation between villagers and local governments. Fei and $\mathrm{Wu}$ emphasize that clan gentries are the constitutors and inheritors of clan rules, and the gentries and conventions are the cornerstones of rural organizations. They also find that it will be difficult for a clan to carry out highly organized activities in traditional villages if there is no gentries' acquiescence or conventions' acknowledgement [5]. Webber indicates that village gentries through equitable use of clan conventions, always strive for the welfare of villagers by affecting local officials and thus get high reputation in local areas [2].

Scholars usually agree that clans are undergoing profound changes, but they hold different views on what drives the changes and how clans change. The relevant research might be broadly divided into three categories. The first category is about "New Community". Under the combined effects of internal and external forces, villages are transformed from communities of unitary clan structures into a comprehensive system which integrates geographical or consanguineous groups, immigrants, modern social organizations and administrative or political units [6,7]. The second category is about "endogenous development", which claims that the "endogenous" factors (those originating within the system) seem much more important than exogenous ones. This is reflected in the emergence of new "big villages" or "super villages" as a result of urbanization [8]. The relevant studies reveal that the influence of clans is strengthening and candidates from large clans are more likely to be elected in elections than that from small ones $[9,10]$. The third category is about "powerful state power", which focuses on the changes of clans from the perspective of coverage of "external" state power. With the strong participation of state power, clan rules gradually evolve into rules of "flexible governance" and are constantly internalized as an important component of the values of rural life [11,12].

Existing literature on this topic falls into two categories: "eco-social" and "adaptive" perspectives. Some researchers suggest that community transitions be understood from an "eco-social" perspective. Inspired both by considerable experience in Latin America and in the United States, Soluri claims that the creation and transition of communities based on sustainable and equitable resource use will require the construction of participatory democracies [13]. Schlosberg and Carruthers illustrate with two in-depth case studies from the US and Chile that environmental challenges raised by local communities demonstrate a broad and complex influence on a range of capabilities and basic functioning at both the individual and community levels [14]. Hettiarachchi et al. investigates the recent ecological transformations in the urban wetlands of Colombo, Sri Lanka, and conclude that from 1980 onwards, the Colombo urban wetlands have undergone an overall transformation in both wetland type (composition and structure) and the social setting. Hydrological modification and watershed urbanization were identified as the main causes of transformations occurring in eco-social landscapes. These transformations often result in "novel" or "hybrid" ecosystems that differ from the original ecosystems both in ecological character and social setting [15].

Meanwhile, other researchers focus on clans or communities' adaption to environmental challenges. Whyte claims that federally recognized tribes must adapt to ecological challenges arising from climate change [16]. Shackleton et al. argue that local-level studies that reveal barriers to adaptation are diverse. They argue that research on barriers needs to start asking why these barriers emerge and how they work together to shape adaptation processes. A considerable part of such research is on the vulnerable communities' adaption to environmental challenges [17]. Briguglio argues that tribes 
of many small island developing states (SIDS) face special disadvantages associated with small size, insularity, remoteness and proneness to natural disasters [18]. After examining three cases of Pacific island atoll nations, where the first signs of climate change are being felt worst and first, Bradley et al. claim that local communities are brutally vulnerable to forces outside their control [19].

However, most of these studies on ecological resource crises in rural areas fall into two main categories: one is about the resource governance and the other about poverty, social conflicts and social movements caused by the resource problems [20-22]. Although some studies, as reviewed in the previous paragraphs, have begun to discuss clan transitions from the perspective of ecological resource crises, they might fail to pay enough attention to the following important points: the differentiation and reorganization of the internal interest groups of clans, the formation of interest groups across clans and its influence on clan boundaries, the changing trends of clans of different scales, and the interaction between clans and political power.

\section{Methods}

\subsection{Study Area}

To enhance understanding of these points, we take Dong Village, an old fishery village situated on the east coast of Shijiu Lake in China, as an example to show how resource crises affect clans and societal changes in rural China. Shijiu Lake, located in the south of Jiangsu Province of China, is a large lake on a low-lying alluvial plain by the Yangtze River. It covers an area of about 207.65 square kilometers and its maximum water storage is appropriately 1 billion cubic meters. In recent decades, hundreds of small chemical fertilizer plants, paper mills and pesticide factories have been established by the lake. The waste water from these factories, together with domestic sewage and agricultural pollution, leads to the acceleration of eutrophication and the decline of waters quality. Dong is an old fishery village situated on the east coast of the lake. The traditional fishery of the village is seriously affected by water pollution, and the main source of the pollution is Tengfei Chemical Industrial Park which is just located beside the village.

There are two main reasons why we choose Dong Village as our research object: First, the clans in the village are characterized by diversity. There are two large clans (Clan Zhou and Clan Wang, number of people 356 and 445, respectively) and a number of small clans (total number of people 298). Moreover, these clans hold different attitudes towards traditional fisheries: Some hoped to adhere, while others give up. This helps us to observe the changes of characteristics of different clans. Second, the first election in Dong took place in 2010, and Tengfei Chemical Industrial Park was established in the same year. The increasing pollution of the industrial park has coincided with the development of village elections, which provides us with a good opportunity to observe constantly adjusting clan ties and clans' increasing interest in participating in village governance.

\subsection{Data Collection and Analysis}

To fully understand the changes of attitudes or behaviors of villagers and transitions of internal or external relations of clans, we developed a chronological framework for our field research. We adopted participatory observations, formal semi-structured interviews and informal interviews to conduct qualitative analysis of major stages. We formulated and adjusted corresponding research methods according to the characteristics of objects of observation, which included villagers' actions to the environment pollution, negotiations between clans, village elections and village politics.

Since most villagers were reluctant to talk openly about their actions against the government and the industrial park, we collected information through informal interviews. We randomly selected the interviewees who had once participated in environmental rights actions and held 45 informal interviews with them. According to the results of interviews, we categorized the types of environmental actions of the villagers (violent or mild), and analyzed their motivation and results. The purpose of data analysis was to understand types or trends of individual and collective actions and the effects of 
these actions on clans. We also took five semi-structured interviews with the officials of the township to understand the government's attitudes towards the villagers' actions and the measures to deal with them. They included the mayor and the two assistant mayors of the township, the party secretary of the township, and some directors of the bureaus of environment or public security of the county. We analyzed recorded dialogues comprehensively to understand the attitudes of township and the party branch.

With the transition from violence to negotiations, the villagers gradually turned to a more peaceful and rational way than before. We attended and observed all the three rounds of clan negotiations and conducted three semi-structured interviews with members of the village committee to collect information on the proportion of fishermen in different clans, the financial revenue of fishery and the chemical industrial park for the village and the quality of drinking water (both the surface water and ground water). The interviewees were randomly selected. The emphasis of field research in this phase was to understand how the ecological crises led to the emergence of new interest groups, and how these groups affected external and internal relations of clans.

Village elections are important events in villagers' lives. We observed the village assembly election for the village head and representatives of the village assembly (we also analyzed the previous two elections through three semi-structured interviews). We recorded the process of the election and compared it with the past elections, aiming to find out how the elections affected clan relations. After the 2014 election, we conducted six semi-structured interviews with emerging élites of clans and representatives of new interest groups from clans of different sizes to understand their attitudes towards the election. The élites interviewed were randomly selected. We recorded and analyzed the results of the interviews to understand how clans of different sizes participated in village governance. village assembly After the election, we observed three meetings of the village assembly and conducted six semi-structured interviews with some delegates and township officials. The delegates were randomly selected while the officials were not. The officials must include the Party secretaries at the both levels of the township and village, and directors of some important bureaus (environment, economy or public security of the county). We focused on the functions of the assembly, the composition of the delegates of the assembly and the attitude of the township government. We hoped to understand changes of status of the traditional clan conferences in dealing with village affairs after the emergence of the assembly.

\section{Results}

\subsection{Observed Results from Events}

\subsubsection{Environmental Rights Action (2010-2012): A Growing Tendency towards Moderation}

When the interests of clans were threatened, the clan gentries used to encourage clan members to take extreme actions, known as "weapons of the weak", to show their determination and strength before governments. For instance, Clan gentries asked the members to block roads and destroy facilities because of a road development project.

The ecological resource crises had different impacts on the two large clans. Clan Zhou still maintained its distinctive features in terms of consanguinity, habitation and etiquette although the interests of the clan members have been diversified. Through a variety of ritual activities such as restocking ceremonies, fishing ceremonies, spectrum repair, worship, weddings and funerals, Clan Zhou strengthened its members' sense of belonging. Once faced with external pressure, the clan would be able to form a strong internal strength to contend with it. However, some new clan élites and most of the clan members claimed that they no longer wanted to adopt violence (such as blocking roads or damaging factories) against governments and the chemical industrial park.

While the gentries of Clan Zhou claimed that they still had strong influence on most of the clan members in environmental rights action, the gentries of Clan Wang found that their tough attitude towards the resource crises no longer received positive responses from its members. They admitted 
that their influence had been transcended by many emerging élites who unequivocally opposed uncooperative attitudes and could expertly negotiated with the township municipal government in technical terms. Moreover, some economic élites share-holding chemical plants have publicly supported the chemical industrial park, and some political élites holding positions in the village committee have warned the clan members not go too far in their protest the chemical plants. A few political élites also claimed that they had asked their extended families to avoid radical actions to establish an image of "political correctness".

Some villagers of Clan Wang were soon warned by the clan élites after they destroyed drainage pipelines of a chemical plant and blocked the road to chemical Park in June, 2012. The clan élites admitted that they have been warned by the party branch secretary of Dong Village. Subsequently, they only presented peaceful petitions to the township government, which were more moderate than before. When asked why they adopted moderate ways of protesting, most villagers admitted that their choice of environmental rights action was largely dependent on the attitudes of clan élites instead of clan gentries. As they put it, most of the villagers, with fewer resources and limited mobility, lived in the lower strata of the clan. It was advisable for them to follow the instructions of the clan élites instead of the clan gentries since the clan élites possessed much richer and more direct political or economic resources (for instance, they knew more entrepreneurs and officials and thus had more reliable and richer information) than clan gentries. Some villagers also admitted that their words and actions do not accord: they claimed to be "aggressive and destructive", but they actually acted prudently or symbolically.

The attitude of most villagers of Clan Wang then became blurred: they neither supported nor opposed environmental rights action. They did not support the environmental action mainly because many of them have gradually abandoned traditional fishery and engaged in non-fishery work such as transportation or installation, and some villagers even worked in the chemical plants. They also did not openly oppose the environmental rights action since some of their relatives still engaged in fishery.

There existed "free riding" in terms of interests and pollution in Clan Wang or Zhou. The so-called "free riders" of interests referred to the villagers who were not involved in protests but might had the same amount of compensation as those who took part in the protests. The so-called "free riders" of pollution referred to the villagers who discharged untreated kitchen garbage into the lake. They shifted the responsibility for environmental pollution to the chemical industry park.

The township municipal government has also shifted its standard of political stability from "rigidness" to "flexibility". "Rigid stability" refers to a social state in which social stability is regarded as absolute governance objectives and governments take all means to suppress or combat any protest, while "flexible stability" indicates a social state in which the society maintains a stable state with an open, dynamic and a strong self-repair function of the stability mechanism. Some officials claimed that the local governments encouraged the new clan élites to strengthen their links with clan gentries or clan members and hoped that clans might become a buffer zone of conflict. The officials also stressed that the clans who cooperate with the governments will obtain economic or political support from governments.

\subsubsection{Negotiations between Two Large Clans (2013): External and Internal Relations in Adjustment}

The conciliatory attitudes of the two major clans stemmed from their different level of dependency on fishery resources. Approximately eight-tenths of the total household income of Clan Zhou comes from fishery in 2013, while only one-tenth of the income of Clan Wang comes from fishery in 2013 and the ratio continued to decline. Many of them worked with the chemical plants and some élites even hold shares of the chemical plants. Some villagers regarded the chemical plants as an opportunity to transit from fishery to non-fishery livelihoods.

To coordinate their position on the fishery crisis, the two clans conducted three rounds of clan negotiations. In the first round of negotiation, some élites of Clan Wang took an uncompromising stand against fishery. As some representatives argued, the chemical industrial park brought about 
869,000 yuan of financial revenue for the village, while the fishing industry could only bring about less than 52,700 yuan in 2012. They thought they had to find a way to make a living since fishery resources were depleted.

Shortly after the first round of negotiation, serious blue-green algae boomed in June 2013 due to surplus phosphorus from chemical factories, as well as domestic sewage. The two clans held the second round of negotiation and they unanimously asked the village committee to drill five wells for temporary water sources for the villagers as an emergency measure. However, the villagers soon found that the well-water had also been contaminated to varying degrees because some industrial waste water discharged into underground sewer ditches without treatment had infiltrated into groundwater aquifer. Groundwater pollution impelled Clan Wang to split into two distinct factions: one still supported the chemical industry while the other opposed. Some villagers were optimistic that the pollution could be controlled with the support of the government, while others were rather pessimistic because they thought that water quality of the great lakes nearby, such as Taihu Lake and Gucheng Lake, had continued to decline although the government has invested huge amount of manpower and money. Different from Clan Wang, most of the villagers from Clan Zhou were not willing to giving up fishery and strongly required governments to take measures to remove the chemical industry park away from the village as soon as possible.

Surprisingly, the two large clans did not directly discuss the environmental issues in the third round of negotiation. Instead, they invited other small clans to attend their meeting, discussing the establishment of an electoral committee for the preparation of village election which would be held two months later. They established an electoral committee of nine people in proportion to the number of clans. The most notable result of the third negotiation, as some villagers said, was that the electoral committee agreed the nomination of two candidates for village head and 21 seats for the Villager's Assembly. The two candidates for village head were from Clan Zhou and Wang, respectively, and they held opposite attitudes towards the chemical industrial park. Many villagers admitted that they were very concerned about the upcoming election because the election has an unprecedented uncertainty and its result had a fundamental impact on their future livelihoods.

\subsubsection{Village Elections (2014): The Exchange of Interests between Large and Small Clans}

There have been two elections in the Village of Dong since 2005 and unsurprisingly candidates from Clan Wang were elected as village heads in the two elections since Wang is the largest clan with the largest number of voters. Some villagers form Clan Wang said that their clan gentries had absolute influence on the clans' voters in the past elections. At their call, the voters would adjust their own interest expectation and keep their votes in line with the clan. Many villagers from small clans complained that there was no suspense in the past elections because it was very difficult for the small clans to win over their large counterparts.

Interestingly, Clan Zhou, whose number of voters was $23 \%$ less than that of Clan Wang, won the election of 2014. There were two factors, as some voters explained, that accounted for the unexpected election results. First, the voters from Clan Wang evolved into different interest groups. This made it difficult for them to achieve consistency and coordination in the election. Second, although the number of voters from Clan Zhou was less than that of Wang, Clan Zhou canvassed for itself among small clans such as Chen and Wang to gain its advantage in the election. As some voters indicated, it was the first time for them to witness corporation between clans of different sizes in elections.

Not only did the small clans play a key role in the election of the village head, they also made satisfactory results in the subsequent elections of the villager's assembly: of the 21 seats, small clans accounted for 11. This, as some villagers put it, was the successful application of small clans' strategy of "Votes for Seats": The small clans got their seats in the assembly by supporting large clans in village head election. Most of the delegates of the villager's assembly have been asked to "talk" with the party secretary of the township or the party branch secretary of Dong Village. Some delegates indicated that the party leaders had asked them to "try to maintain a stable and harmonious political situation". 


\subsubsection{The Village Politics (2015-2017): The Increasingly Prominent Position of the Villagers' Assembly}

Villagers used to discuss clan affairs in traditional clan conferences and follow the decisions made by clan meetings without any questioning. However, they found that clans meetings could not solve matters that cross clans. The villagers' assembly, as some villagers stated, consists of delegates from different clans or interest groups and thus might best represent the interests of different villagers. The assembly gradually replaced traditional clan conferences and acted as an important platform for villagers to discuss resource crises and other affairs. When it came to the causes of this shift, some delegates explained that the villagers' assembly, elected rather than appointed, was regarded as an institution which is more formal and trustworthy than traditional clan conferences. They thought that although there was some bickering in the assembly, it was usually the first step in solving problems.

Besides, the assembly, as some delegates commented, increased their political consciousness and aroused their enthusiasm for political participation. Some delegates said that they, as villagers' representatives, no longer represented their own or their clans' interests. They needed to think about a broader range of interests when they talked or even argued with other delegates. In the face of the complexity of ecological resource crises, they must consider both the stakeholders involved in the chemical industry and the long-term impact of environmental pollution. They often needed to discuss with counterparts from other clans and officials or entrepreneurs who attended the assembly meetings.

The township officials also commented that the assembly had become a new channel for the township government to negotiate with the clans and even the whole village. Some officials said that township government used to settle villager disputes by holding informal or private consultations with clan gentries. However, it was now rather difficult for the officials to settle disputes through such consultations because ecological resource crises had led to the serious disintegration of clan interests and clan gentries no longer represented the interests of the whole clan. Some officials admitted that they preferred to contact the delegates of the villagers' assembly rather than clan gentries. Besides, the mayor even regarded the assembly as a buffer to reduce the possibilities of violence among clans. Discussions or even quarrels in the assembly, as the mayor said, might reduce the possibilities of social conflicts.

\subsection{Reflections on These Events over Time}

\subsubsection{Within Clans: The Rise of New Clanism}

Although the degree and characteristics of their changes are different, the close ties inherent in the two large clans begin to wane. Clan Zhou, despite its traditional mechanical solidarity, has begun to show signs of fragmentation. Clan Wang, showing an obvious characteristic of organic solidarity, holds a more tolerant attitude towards changes. A case in point is that it does not object to its members' engagement in non-fishery work. Many villagers of Clan Wang engage in work directly or indirectly related to chemical industry, such as operation and inspection of chemical equipment, building of lightweight steel workshops, transportation of chemical products, and even catering or hospitality industry. They began to establish heterogeneous and interdependent social connections and form a social relation of "reciprocal existence". This means that they have formed relatively closed "sub systems" without having to consider the whole clan [23,24].

The formation of "reciprocal existence" and "sub systems" indicates that the rigid orders loosen and "new clannism", a new clan doctrine, is being established [25]. "New clannism" refers to a new clan state in which new élites gradually replace gentries as the new authorities of villages, and villagers establish equal and consultative social relationship. "New clannism" could be explained from two perspectives. As for individual villagers, they understand kinship and geopolitical resources are no guarantee of full personal development. The tightness of kinship has been weakened, and economic considerations, instead of kinship, has become an important guiding principle in their social or economic exchanges [26,27]. The rationalization of their actions leads to the enforcement of instrumental relations. As for the whole clans, the influence of traditional clan rules began to decline, 
while legal authority and state power promote the establishment of new norms. Class differentiation of clans is gradually emerging, which contributes to the creation of new interest groups [28,29].

\subsubsection{Across Clans: Changing Boundaries}

Overall, clan boundaries get increasingly obscure but remain relatively distinct. The main reason for the blurring of boundaries is the change in the pattern of interests brought about by natural resource crises. In the crises, the villagers whose interest demands cannot be fully met within their own clan have to seek help from the interest groups of other clans. This leads to the overlap of interests and emergence of new interest groups across clans. Individuals' tendency to cater for the interests directly weakens the basis of a clan's group action and results in the vagueness of clan boundaries.

However, there still exist hidden but influential lines of demarcation among clans. The boundary has two functions: ensuring the villagers of same clans share the greatest benefits and eliminating the possibilities of other clans' free riding. Inherent closeness and exclusiveness of a clan could both maintain a community of shared interests and exclude "free riders" from other clans.

In particular, the dynamic relationship between large and small clans can clearly reflect the coexistence of ambiguity and clarity of clan boundaries. Large clans usually hold dominant positions in village governance and actively exert their influence on small clans. Small clans, in the premise of maintaining their relative independence, usually manage to occupy a favorable position in the competition for natural resources by seeking delicate balance among large clans and seeking for political spaces of their own in village governance. However, it seems unlikely that the small and large clans would amalgamate in the foreseeable future. If the small clans were the first to sacrifice their own interests to fully combine with the large clans, it is difficult for the new consortium to construct larger borders to accommodate all the separate entities. The attempt to satisfying the interests of the new consortium might eventually lead to its dissolution.

\subsubsection{Clans and Local Governance: The Infiltration of New Élite Forces into Village Governance}

The politics of traditional villages used to base on rural conventions, which signified the low degree of villager participation of in village politics and exclusion of village politics from the system of state power. The villager's stratification gradually formed recent decades and some new élites successfully gain access to positions in village governance. They express their opinions, participate in decision-making activities and coordinate their conflicts of interest through formal political mechanism or approaches such as village elections or the villagers' assembly [30]. It indicates that villagers' goals of competition have shifted from ecological resources to political or social capital.

Although the new élites might temporarily abandon the shackles of clan rules and resolve their divergence in the framework of modern political system, the limits of new élites to participate in village governance are not unconditional and infinite [31]. In view of the new élites and clan gentries are still inextricably linked, the new élites will still have to resort to the micro rural conventions once their conflicts of interest cannot be properly resolved in the macro political framework. A case in point is that if some new élites want to pass a resolution in the assembly, they must try to get the support of most of the delegates, who may be closely related to their own clan gentries. Obviously, the gentries also want to extend their influence on village governance through the new élites.

The participation of new élites in village governance also depends on the openness and tolerance of the state power and the scope of rights set by the Constitution and relative laws. Although new élites are rising rapidly, their political capital is relative weak in contrast to the local government, which is the embodiment of state power in the village and undoubtedly owns powerful political resources [32]. In the face of a powerful government, the new élites have to act cautiously in the village committee or assembly. 
3.2.4. Power Struggle between Village Heads and Party Branch Secretaries of Villages, and Clan Gentries and New Élites

The traditional structure of China's governance is composed of two levels. The upper level is a top-down bureaucratic system which consists of the mutual-constrained central and local governments, while the lower level comprises "relatively independent kingdoms", which are led by village gentries. The highly centralized system usually devolves some power to local gentries, who control villages not only by the power delegated from the above, but also by the prestige they gain among the villagers. One of the most important features of the traditional China's politics is the instability of the upper hierarchy and stability of the grass-roots "politics". However, this has been reversed since the Communist Party of China came into power in the 1950s of last century: The upper layer becomes stable while the lower began to unrest. The party takes two seemingly contradictory strategies: maintaining village autonomy by introducing elections to villages and monitoring village affairs by establishing the party branches in the villages. This has resulted in two kinds of power struggles.

The first is the conflicts between party branch secretaries of villages and village heads. Although a secretary and a village head are co-leaders of a village, the secretary has a stronger voice than a village head as the secretary is appointed by the superior while the head is elected by villagers. The result of the struggle between them usually ends with the resignation of the head or an early election.

The second is the clashes between gentries and new élites. Gentries usually exert their influence over village governance through clan power or clan rules while élites, representatives of cross-clan interest groups, also wish to take full part in the politics of villages. However, the consequences of the clashes depend on some complex factors such as attitudes from "the above", economic development planning, resource endowment of villages and combination of interests between different groups.

\section{Discussion}

At present, the debate of clan studies focuses on whether clans are reviving or fading. The renaissance theorists argue that the loose political environment in China has led to the growth of patriarchal clan forces that have remained silent for many years and the enhanced patriarchal organizations have the ability to resist external pressures $[9,10,21]$, while the extinction theorists believe that villagers have begun their process of "citizenship" since China's reform and opening up and the kinship of clans are being replaced by the social contract between the state and the citizens $[26,28]$. However, our research shows that the situation seems much more complicated. We might observe the at least three unique clan changes from the point of view of sustainable community development.

The first is about what is happening within clans. Traditional clan rules are moving from rigidity to flexibility and clan gentries gradually lost their sacred authority entrusted by traditional patriarchal ethics. However, the changes do not seem to lead to, as some researchers have pessimistically claimed, "a traditional community that has almost completely changed or even no longer exists" [6,7]. Although the rise of the new élites in Clan Zhou shook the prestige of its clan gentries, the influence of the gentries is still widespread both in traditional areas (fisheries) and in modern field (canvassing). Our case study shows that gradual and transitional clan changes are likely to occur in a traditional village under great environmental pressure, and the gradual transition (instead of sudden changes) is an important basis for maintaining social stability and sustainable development of villages in China.

The second is concerned with what is happening across clans. New consultative relationships gradually formed across clans as the village assembly, one of the new formal mechanism, is established. Some small clans might even exert a certain influence on their large counterparts in the routine meetings of the assembly. Clearly, the distinction between the delegates of the assembly is no longer based on clan consanguinity, but rather on new interest groups which emerge across clans. This point is also different from that of the researchers who hold the theory of "endogenous development". The theory claims that the "endogenous" factors (such as clan forces) seem much more important than exogenous ones (such as ecological crises) and that powerful clans who developed on an unprecedented scale would greatly influence and even dominate small clans $[9,10]$. 
The third is about clan power permeating the state power at the village or township levels. It must be pointed out that clans slowly decompose into different interest groups. This is a process of transition from bottom to top: many representatives of the new interest groups are elected as delegates of the village assembly and successfully affect policy making at the village or township level, while state power has begun to adapt to demand of political participation from the delegates and has enacted measures to ensure them to exercise their rights under a legal framework [33]. The return of power in China's rural areas confirms the concept of "concrete utopias" described by Foster. Foster, based on the tradition of Ernst Bloch, Raymond Williams and Rachel Carson, intends his analysis of ecological crisis to lead not to despair but to a politics of hope aimed at rational distribution of political power and resources [34]. Magnani and Struffi analyze the results of an European "research and demonstration" project promoting environmental-friendly agriculture in Alpine regions through a participatory approach. They demonstrate the role of social dynamics in fostering sustainable rural development in a participatory context [35]. This is just contrary to the idea of "powerful state power" in some research, which regards it a process of transition from top to bottom: state power, as an "powerful" and "active" force, affect clans directly and powerfully. Meanwhile, the clans, under the dual pressure of political reform and economic development, are gradually disintegrating [11,12].

Let us turn our attention from the clan transition to the relationship between the ecology and society. Water resources are characterized by liquidity and integrity, which means that water resources, whether surface water or ground water, are an organic whole. Neither a water source nor an aquifer can be treated as an isolated unit. Similarly, clans of Dong Village, as social organizations, are characterized by adaptability and variability. The changes in clan system are adaptive rather than passive as clans are no longer closed circles of villagers and are inclined to adopt inclusive attitudes towards changes in environment. The clans undertake some institutional practices such as policymaking or decision-making concerning resource management within the framework of the modern political and economic systems [36]. These changes will surely contribute to the sustainable development of rural China. However, Buttel argues that the conception of the increased role of "green" forces and the concomitant environmentalization of institutional practices in the United States and elsewhere across the world must be in the transition from social-democratic to neo-conservative regimes of social regulation of economy and society that has occurred during the past 15 or so years of global economic stagnation [37].

Furthermore, society has a dualistic relationship with its environment, being restricted to physical limits of ecology and resources and yet being inimitable in creation of conspicuously social structures with unparalleled complexity $[13,15,18]$. Environmental restriction and social construction (instead of social structure) are interrelated closely and dynamically, which has been presented in some research. Bell et al. find that some villages in Latvians are undergoing profound social and environmental changes because of depopulation and agricultural land abandonment. This, as they argue, are the consequences of unbalanced resource use and uncoordinated development planning [38]. Kassover and Mckeown find that resource development promotes economic development of some rural communities in the western United States of America, but the prosperity of the economy has altered the traditional social structures of the rural communities, and such rapid growth can lead to substantial community disruption and the sluggish development of some industries [39]. The irreplaceable system of ecological resources (water, air, soil, etc.) makes the resources not only a material base of economic development, but also an integral part of sustainable development of the societal system.

\section{Conclusions}

Although it is just a case study and has not been extended to a sampling survey on a larger scale, our research is indeed an attempt to study rural social changes from the perspective of pollution and explore effects of these changes on community sustainability. Some key ecological resources in China's rural areas like water, farmland, forest and grassland are continually deteriorating, mainly characterized by decrease both in quantity and quality $[40,41]$. Through our research, we hope to call on 
the academic circles to pay attention to the continuous and profound impact of ecological degradation on the rural society of China. Since rural areas differ greatly in natural resources endowment and social structures, we need further observation and exploration to ensure a more comprehensive understanding of societal changes in rural China.

Author Contributions: Jiajun $\mathrm{Xu}$ and Yongping Wei contributed to the conception of the study. Jiajun $\mathrm{Xu}$ and Qidong Huang contributed significantly to analysis and manuscript preparation. Qidong Huang performed the data analyses and wrote the manuscript. Yongping Wei helped revised the manuscript.

Conflicts of Interest: The authors declare no conflict of interest.

\section{References}

1. Wang, Y. New Collectivism: The Reorganization of Rural Society; Economic Science Press: Beijing, China, 1996. (In Chinese)

2. Weber, M. The Religion of China: Confucianism and Taoism; Gerth, H.H., Ed.; Free Press: New York, NY, USA, 1968.

3. Fairbank, J.K. The United States and China, 2nd ed.; Harvard University Press: Cambridge, MA, USA, 1958.

4. Fukuyama, F. The Great Disruption: Human Nature and the Reconstitution of Social Order; Free Press: New York, NY, USA, 1999.

5. Fei, X.T.; Wu, H. Imperial Power and Gentry Power; Yuelu Press: Changsha, China, 2012. (In Chinese)

6. Zhao, P. Urban-rural transition in China's metropolises: New trends in peri-urbanization in Beijing. Int. Dev. Plan. Rev. 2012, 3, 269-294. (In Chinese) [CrossRef]

7. Feng, J.F. Peasant migration and rural governance in China. J. Xihua Univ. (Philos. Soc. Sci. Ed.) 2017, 4, 66-71. (In Chinese)

8. Zhe, X.Y.; Chen, Y.Y. The relation between structures and subjects in property right system. Soc. Res. 2000, 5, 32-42. (In Chinese)

9. Xiao, T.B. Study on the relationship between clans, village governance and village election. Jiangxi Soc. Sci. 2001, 9, 125-130. (In Chinese)

10. Liu, J.H. The empirical study of the influence of clans on rural authority and its patterns. Southeast Acad. 2016, 1, 80-87. (In Chinese)

11. Lin, S.M.; Ji, Q. The response of rural society to the village election-Research on the factors affecting villagers' participation in the election. J. Fujian Norm. Univ. (Philos. Soc. Sci.) 2004, 3, 34-52. (In Chinese)

12. Fu, R.L.; Yao, J.Y. The path choice of rural governance in the process of new urbanization. J. Hunan Adm. Coll. 2017, 1, 21-24. (In Chinese)

13. Soluri, J. Trouble in paradise: Globalization and environmental crises in Latin America. Technol. Cult. 2004, 45, 636-638. [CrossRef]

14. Schlosberg, D.; Carruthers, D. Indigenous struggles, environmental justice, and community capabilities. Glob. Environ. Polit. 2009, 10, 12-35. [CrossRef]

15. Hettiarachchi, M.; Morrison, T.H.; Wickramsinghe, D.; Mapa, R.; Alwis, A.D. The eco-social transformation of urban wetlands: A case study of Colombo, Sri Lanka. Landsc. Urban Plan. 2014, 132, 55-68. [CrossRef]

16. Whyte, K.P. Justice forward: Tribes, climate adaptation and responsibility. Clim. Chang. 2013, 120, 517-530. [CrossRef]

17. Shackleton, S.; Ziervogel, G.; Sallu, S.; Gill, T.; Tschakert, P. Why is socially-just climate change adaptation in sub-Saharan Africa so challenging? A review of barriers identified from empirical cases. Wiley Interdiscip. Rev. Clim. Chang. 2015, 6, 321-344. [CrossRef]

18. Briguglio, L. Small island developing states and their economic vulnerabilities. World Dev. 1995, 23, 1615-1632. [CrossRef]

19. Bradley, C.; Parks, J.; Roberts, T. Globalization, vulnerability to climate change, and perceived injustice. Soc. Nat. Resour. 2006, 19, 337-355.

20. Spoor, M. The political economy of rural livelihoods in transition economies: Land, peasants and rural poverty in transition. J. Mol. Neurosci. 2009, 37, 288-300.

21. Li, S.; Ding, S. An empirical analysis of income inequality between a minority and the majority in urban china: The Case of Ningxia Hui Autonomous Region. Rev. Black Polit. Econ. 2013, 40, 341-355. (In Chinese) 
22. Glauben, T.; Herzfeld, T.; Rozelle, S. Persistent poverty in rural china: Where, why, and how to escape? World Dev. 2012, 40, 784-795. [CrossRef]

23. Gu, C.; Li, Y.; Han, S.S. Development and transition of small towns in rural China. Habitat Int. 2015, 50, 110-119. [CrossRef]

24. Ho, S.P.S. Rural China in transition: Non-agricultural development in rural Jiangsu, 1978-1990. Pac. Aff. 1997, 70, 589-601.

25. Yang, L.; Xiao, W.D. On the rural clans and villagers' autonomy in the social governance at the grassroots level. Theor. Obs. 2015, 2, 86-87. (In Chinese)

26. Ma, X. Chinese traditional clan theory. J. Shandong Univ. (Philos. Soc. Sci. Ed.) 2015, 4, 1-13. (In Chinese)

27. Liu, C.L. An analysis of the mobilization mechanism of collective action-An investigation of an village in northern Guangxi. J. Nanjing Agric. Univ. (Soc. Sci. Edit.) 2015, 4, 7-15. (In Chinese)

28. Yuan, J.H. Review and prospect of rural governance in China. J. Yunnan Adm. Coll. 2016, 1, 112-117. (In Chinese)

29. Nie, Y.D. Community autonomy: A new model of rural governance in China. J. China West Norm. Univ. (Soc. Sci. Ed.) 2017, 4, 30-36. (In Chinese)

30. Zhou, T.T. The contemporary form of the rural governance and its function. J. Hunan Agric. Univ. (Soc. Sci. Ed.) 2017, 18, 38-39. (In Chinese)

31. He, X.F. The institutional choice of rural governance. J. Wuhan Univ. Humanit. Sci. Ed. 2016, 69, $25-27$. (In Chinese)

32. Huo, G. The three dimensions of state power intervention in rural governance. Agric. Econ. 2017, 1, $21-23$. (In Chinese)

33. Zou, R. Village culture genes and village politics in contemporary Chinese villages. J. Yunnan Adm. Coll. 2017, 19, 156-162. (In Chinese)

34. Foster, J.B. Marx's Ecology: Materialism and Nature. Contemp. Sociol. 2002, 8, 142-143.

35. Magnani, N.; Struffi, L. Translation sociology and social capital in rural development initiatives. A case study from the Italian Alps. J. Rural Stud. 2009, 25, 231-238.

36. Lin, Z. The mechanism and function of village rules in modern rural governance. Economist 2017, 1, 19-20. (In Chinese)

37. Buttel, F.H. Environmentalization: Origins, Processes, and Implications for Rural Social Change. Rural Sociol. 2010, 57, 1-27. [CrossRef]

38. Bell, S.; Montarzino, A.; Aspinall, P.; Penēze, Z.; Nikodemus, O. Rural Society, Social Inclusion and Landscape Change in Central and Eastern Europe: A Case Study of Latvia. Sociol. Rural. 2010, 49, 295-326. [CrossRef]

39. Kassover, J.; Mckeown, R.L. Resource development, rural communities and rapid growth: Managing social change in the modern boomtown. Miner. Environ. 1981, 3, 47-54. [CrossRef]

40. Gan, L.; Yu, J. Bioenergy transition in rural China: Policy options and co-benefits. Energy Policy 2008, 36, 531-540. (In Chinese)

41. Jiang, L.; O’Neill, B.C. The energy transition in rural China. Int. J. Glob. Energy Issues 2004, 21, 2-26. [CrossRef]

(C) 2018 by the authors. Licensee MDPI, Basel, Switzerland. This article is an open access article distributed under the terms and conditions of the Creative Commons Attribution (CC BY) license (http://creativecommons.org/licenses/by/4.0/). 